\title{
Study Ethnomedicine Betimun: The Traditional Steam Bath Herb of Saibatin Sub-tribe, Lampung
}

\author{
Anisatu Z. Wakhidah ${ }^{1 *}$, Marina Silalahi ${ }^{2}$ \\ ${ }^{l}$ Institut Pertanian Bogor, Indonesia \\ ${ }^{2}$ Universitas Kristen Indonesia, Jakarta, Indonesia \\ *khistia.nisa@gmail.com
}

\begin{abstract}
The saibatin community has a traditional steam bath concoction called betimun. This herb contains many health benefits that come from the composition of used plant species. However, the ethnomedicine study about that herb is still lacked. The purposes of this study were, to explain and document used plant species, parts used, and sources of plant acquisition used in betimun herb; to explain the cooking process of betimun concoction, the usage, and the efficacies; to explain the biological activity of secondary metabolite content in betimun herbs. The ethnobotanical data collected by using a questionnaire interview method then data analyzed using a qualitative approach. The study revealed as many as 6 species from 3 families used in the cooking process of betimun herb, Zingiberaceae was the family with the highest number of species ( 4 species). The used part of all plant species was leaves, while the acquisition source was from homegarden. The betimun herb was made by boiling the plants leaves. The usage way by confining the user with a sarong then the herb placed between his/her legs. Biological activities contained in the secondary metabolite compound composition of betimun herb were anti-fungal, antibacterial, antioxidant, aromatherapy, anti-oxidant, anti-glycation, sedative, antihypertensive, and astringent. This study proved that the betimun concoction has roles in eliminating body odor, fatigue, and aches; preventing and treating vaginal discharge; recovering the postpartum women's condition; slowing down the aging process, and accelerating the metabolic process. Betimun concoction potentially to be developed as a ready-use product such as phyto-simplicia.
\end{abstract}

Keywords: Betimun Concoction, Herbal Medicine, Lampung, Saibatin Community, Steam Bath 


\section{STRADA Jurnal Ilmiah Kesehatan}

DOI: $10.30994 /$ sjik.v9i2.257

ISSN: 2252-3847 (print); 2614-350X (online)

Vol.9 No.2 November 2020 Page.1258-1267

\section{BACKGROUND}

Advancement in the health technology sector does not eliminate the culture of traditional medication in Indonesia. Traditional medication techniques are still in demand by Indonesian people, especially in rural areas that have inadequate health facilities. A steam bath is one traditional medication technique that is still popular today. This treatment aims to remove metabolic waste from the body through sweat by steaming the body with traditional herb (Batubara et al. 2017; Halid \& Novianti 2017; Lonita et al. 2019). Besides it uses to keep health or fitness, the other efficacy of a steam bath is initially intended for postpartum women (Silalahi and Nisyawati 2019). Steam baths can also eliminate body odor because the commonly used plants as ingredients contain a very fragrant aroma (Najamudin 2018; Sarpinah et al. 2018). In addition, the aroma produced also gives an aromatherapy effect, so that a steam bath is believed to be a relaxation treatment (Putri et al. 2017).

Besides being used as a treatment technique, the steam bath also includes a stage in the preparation of a bride before the wedding ceremony. For example, it's encountered in a bridal treatment night of the Bugis tribe (mappassau botting ceremony), a series of steam baths performed for the bride (Sarpinah et al. 2018). The steam baths performed for the bride is also mentioned in a local song lyrics of the Banjar community, entitled Kambang Goyang (Najamudin 2018). Furthermore, the steam bath is performed in the welcoming ceremony of a girl adolescent phase in Gorontalo and West Halmahera as well. That ceremony is held when a girl got her first menstrual cycle (Halid \& Novianti 2017; Wakhidah et al. 2017). Those various utilizations indicate that the steam bath is very closely related to the daily life of the Indonesian people..

Due to the steam baths is used extensively by various Indonesian society, its name can be different in each area. Oukup is a steam bath concoction from Karo Batak tribe (Batubara et al. 2017; Silalahi and Nisyawati 2019); betangas steam bath concoction from Malay Sintang community (Putri et al. 2017); timung or batimung is a steam bath from the Banjar community and Dayak Kenyah tribe (Najamudin 2018; Lonita et al. 2019); molungudu is a steam bath from Gorontalo (Halid \& Novianti 2017); while bafufu is a steam bath from Ternate tribe, West Halmahera (Wakhidah et al. 2017). Besides having different names, the plant material used in those steam bath concoction also varies. Silalahi and Nisyawati (2019) state the main ingredients used in a steam bath are plants that produce volatile oil compounds which have a distinctive aroma.

The Lampung saibatin sub-tribe is one of the indigenous peoples in Indonesia who still uphold their cultural customs. The indigenous people live in coastal and hills areas in the Lampung province. The saibatin community also has a steam bath concoction called betimun. This concoction has not been reported regarding the composition of used plants and preparation. The knowledge of the betimun steam bath concoction may be lost due to a lack of this knowledge documentation. Therefore, the ethnomedicine study of betimun herb is important to do.

The purpose of this study is to elaborate and document the used plant species in the betimun concoctions, the used plant parts, and the sources of the plant; to explain the preparation process of betimun herbs, usage procedure, and the believed efficacies by the saibatin community; to explain the content of secondary metabolites and their pharmacological activity of used plant species in the betimun concoction based on literature review. 


\section{STRADA Jurnal Ilmiah Kesehatan}

DOI: $10.30994 /$ sjik.v9i2.257

ISSN: 2252-3847 (print); 2614-350X (online)

Vol.9 No.2 November 2020 Page.1258-1267

\section{METHODS \\ Research Site}

The study was conducted at Labuhan Mandi and Kegeringan Village, Lampung. Labuhan Mandi Village is located in Way Krui Subdistrict, Pesisir Barat Regency. This village is bordered by Bukit Barisan Selatan National Park (TNBBS) to the north; Gunung Kemala Village to the south; Way Gunung Village in the west and Babat Tumbai Village in the east. The village distance to the district capital is $\pm 5 \mathrm{~km}$, while the provincial capital is $\pm 385 \mathrm{~km}$. The majority livelihoods of Labuhan Mandi people are farming (98.5\%), both as field or garden farmers and as farm laborers. The rest work as civil servants (1\%) and TNI / POLRI (0.45\%) (Dirjen Bina Pemdes 2017).

Meanwhile, Kegeringan Village is located in Batu Brak Subdistrict, West Lampung Regency. This village is bordered by Gunung Sugih Village in the north; Sukabumi Village in the south; Balak Village to the east; and Kembahang Village in the west (Dirjen Bina Pemdes 2017). The village distance to the district capital is $\pm 9.4 \mathrm{~km}$, while the provincial capital is $\pm 191 \mathrm{~km}$. Most of the people of Kegeringan work as farmers (33\%), while other professions, civil servants $(2.1 \%)$, laborers $(15 \%)$, and casual workers (7.7) (Dirjen Bina Pemdes 2017). Both sites were chosen because of most the villager's population is a saibatin community. Besides that, medicinal shamans who had a lot of knowledge about the herbs, are still existed there.

\section{Data Collection and Analysis}

The research was conducted from November until December 2018. We determined key respondents by using purposive sampling methods. Key respondents were drug shamans in both villages. Ethnobotanical data were collected through a questionnaire interview method (Volg et al. 2004). We also did the same sampling and interview method on 30-40 common respondents (Hoffman et al. 2007). The used plant species in the preparation of betimun herb were recorded the local and scientific names in the field. If an unidentified species was found, the species was photographed for its every morphological character and then identified by asking the plant taxonomist. The content of secondary metabolites and pharmacological activity of each used plant species were obtained from the literature review. Then, It related to the efficacy of the betimun herb that believed by the saibatin community. Furthermore, the research data were analyzed using a qualitative approach then presented in tabular form and explained descriptively.

\section{RESULT AND DISCUSSION}

\section{The Plant Composition in Preparing Betimun}

As many as 6 plant species belonged to 3 families were needed by the Saibatin community in preparation of betimun herb. The most widely used species came from Zingiberaceae (4 species), while the remaining 2 species were from Asteraceae and Poaceae. This number is lesser than the used plant in steam bath concoction found in other indigenous peoples in Indonesia. The Batak Karo people use at least 69 species classified to 48 families to make Oukup herb (Batubara et al., 2017). However, the number of those plant species is quite similar to the number used plants in the steam bath concoction in the Dayak Kenyah community, as many as 5 species belonging to 5 families (Lonita et al., 2019). Likewise, the number of used plants in steam bath concoction at mappassau botting ceremony which is only 4 species from 4 families (Sarpinah et al., 2018). 


\section{STRADA Jurnal Ilmiah Kesehatan}

DOI: $10.30994 /$ sjik.v9i2.257

ISSN: 2252-3847 (print); 2614-350X (online)

Vol.9 No.2 November 2020 Page.1258-1267

Tabel 1 The list used plants species in preparing betimun herb the traditional steam bath of Saibatin community, Lampung

\begin{tabular}{llccc}
\hline Local name & Scientific name & Families & $\begin{array}{c}\text { Used part of } \\
\text { plants }\end{array}$ & Plant source \\
\hline Capa & Blumea balsamifera & Asteraceae & leaves & pekarangan \\
Cekur & Kaempferia galanga & Zingiberaceae & leaves & pekarangan \\
Jakhi & Zingiber officinale & Zingiberaceae & leaves & pekarangan \\
Kunyikh & Curcuma longa & Zingiberaceae & leaves & pekarangan \\
Lawas & Alpinia galanga & Zingiberaceae & leaves & pekarangan \\
Sekhai & Cymbopogon citratus & Poaceae & leaves & pekarangan \\
\hline
\end{tabular}

Zingiberaceae has been widely used as medicinal ingredients. A study on the secondary metabolite content of the Zingiberaceae species has also been carried out a lot. The secondary metabolite compounds in Zingiberaceae have various biological activities such as anti-fungal, anti-bacterial, antioxidant, antimicrobial, and antiglycation (Jirovetz et al., 2003; Kanjanapothi et al., 2004; Bhuiyan et al., 2008; Mustafa et al., 2010; Coal et al., 2016; Kaban et al., 2016; Pulungan 2017). Thus, the local knowledge of the saibatin community regarding the medicinal efficacy of Zingiberaceae in betimun herb has been scientifically proven.

Leaves were part of all plant species that used in the betimun herb (6 species). This is different compared to the various used parts of plants that needed in the preparation of steam bath concoctions in other areas, such as tubers, fruit, flowers, and stems (Batubara et al., 2017; Putri et al., 2017; Lonita et al., 2019). The utilization of leaves was preferable by the saibatin community likely due to leaves are the most abundant part of plants and easier to obtain than other parts (Gazzaneo et al., 2005; Amiri et al., 2012). In terms of ethics, a content of certain secondary metabolites is more abundant in leaves than other parts of some plant species, such as citral in Cymbopogon citratus (Sofiah 2010) and compounds making up essential oils in Blumea balsamifera (Jiang et al., 2014).

The source of all used plant species in the betimun herb was harvested from homegarden. This indicates that the community in both villages had managed their homegarden to meet their daily medicinal needs, such as the plant species used in betimun herb. In addition, those plant species were not only used as medicinal ingredients, but the saibatin community also used 5 of 6 species as spices and as a beverage. Meanwhile, the leaves of Blumea balsamifera was believed to be internal medicine. Since those plant species have more than one use with frequent usage, many of them were cultivated by the saibatin community.

\section{The Preparation of Betimun Herb and Its Usage}

The saibatin community prepared the betimun herb by boiling leaves of the used species (Table 1). The boiling process is an extraction method to secrete an active compound of plants intended to dissolve in water or other solvents so it can be more easily utilized (MOH RI 2000). The steam of boiled herbs was used to performing steam baths or for bathing after mixing with cold water. The betimun itself was carried out in a way, the person who is going to take a steam bath is covered in a sarong and then the betimun herb is placed between his legs. The resulting steam is believed to have the effect of refreshing the body, producing fragrant aroma, warming the body, restoring the condition of the body 


\section{STRADA Jurnal Ilmiah Kesehatan}

DOI: $10.30994 /$ sjik.v9i2.257

ISSN: 2252-3847 (print); 2614-350X (online)

Vol.9 No.2 November 2020 Page.1258-1267

after giving birth, and treating gout. The saibatin community usually uses betimun herb to relieve fatigue and aches after returning from the garden. Similar to the Batak ethnic in North Sumatra, they tend to use plants that rich in essential oil. The Batak ethnic use medicinal plants that can withstand evaporation such as Melastoma, iso that the steam aroma can be maintained longer (Silalahi and Nisyawati 2019).

Table 2. The Phytochemical content and pharmacological activities of used plant species in preparing betimun herb - the traditional steam bath of the saibatin community, Lampung

\begin{tabular}{cll}
\hline \multicolumn{1}{c}{ Scientific name } & \multicolumn{1}{c}{ Phytochemical Content } & Pharmacological Activities \\
\hline Alpinia galanga & Essential oils: & \\
& 1,8-cineole $(28,3 \%)$, camphor (15,6\%), $\beta$ - & Aromatherapy (Jirovetz et al. \\
& pinene $(5,0 \%),(\mathrm{E})$-methyl cinnamate $(4,6 \%), 2003)$ anti-bacterial (Rao et \\
& bornyl acetate (4.3\%), guaiol (3.5\%) (Jirovetz al. 2010) \\
& et al. 2003) \\
& methanol, acetone and diethyl ether (Rao et \\
& al. 2010)
\end{tabular}

Blumea balsamifera

Curcuma longa alkaloid, steroid/triterpenoid, flavonoid, saponin, tannin (Maslahat et al. 2017) minyak atsiri: caryophyllene (19.28\%); 1,7,7- antioxidant (Jiang et al. 2014) trimethyl-(1S-endo)-bicyclo[2.2.1] heptan-2ol (15.54\%); caryophylleneoxide (11.20\%); thujopsene (10.36\%); 3-t-butyl-4methoxyphenol methyl derivative $(6.04 \%)$; guaiol (5.03\%); 1,3,4,5,6,7-hexahydro-2,5,5trimethyl-2H-2,4 $\alpha$ - ethanonaphthalene (4.89\%); decahydro- $\alpha, \alpha, 4 \alpha$-trimethyl-8methylene- [2R- $(2 \alpha, 4 \alpha \alpha, 8 \alpha \alpha)]-2-$ naphthalenemethanol (3.83\%); $1 \alpha, 2,3,3 \alpha$, 4,5,6,7 $\beta$-octahydro- 1,1,3 $\alpha, 7$-tetramethyl[1 $\alpha \mathrm{R}-(1 \alpha \alpha, 3 \alpha \alpha, 7 \alpha \beta)]-1 \mathrm{H}$-cyclopropa [a] naphthalene (2.97\%); 4,4-dimethyltetracyclo [6.3.2.0(2,5).0(1,8)] tridecan-9-ol $(2.54 \%)$ (Jiang et al. 2014)

antibacterial and astringent effect (Ruhimat 2016) antioxidant activity (Maslahat et al. 2017) antitumor and sineol, borneol, landerol, kamper, tanin, saponin, damar, ksantoksilin , flavonoid (Ruhimat 2016)
Cymbopogon citratus
Curcuma longa 2015) (Septiana \& Simanjuntak
Saponin, flavonoid, tannin (Pulungan 2017) 2015) anti-fungi (Pulungan 2017) Sitral (Sofiah 2010; Manus 2016) anti-bacterial (Manus 2016); flavonoid, alkaloid, tanin, polifenol, saponin anti-fungi, aromatherapy (Kawenginan et al. 2017) (Sofiah 2010) anti-bacterial (Kawenginan et al. 2017)

steroid; triterpenoid (Septiana \& Simanjuntak anti-fungal, anti-bacterial 


\section{STRADA Jurnal Ilmiah Kesehatan}

DOI: $10.30994 /$ sjik.v9i2.257

ISSN: 2252-3847 (print); 2614-350X (online)

Vol.9 No.2 November 2020 Page.1258-1267

\begin{tabular}{|c|c|c|}
\hline Kaempferia galanga & $\begin{array}{l}\text { Ethyl-cinnamate (Othman et al. 2006) } \\
\text { hexane extract; ethyl trans-p- } \\
\text { methoxycinamate; ethyl-cinnamate (Huang et } \\
\text { al. 2008) } \\
\text { phenolic content; flavonoids, including } \\
\text { luteolin; apigenin (Mustafa et al. 2010) } \\
\text { Ethyl-p-methoxycinnamate (Kanjanapothi et } \\
\text { al. 2004) } \\
\text { Linoleoyl chloride and 2- propenoic acid, 3- } \\
\text { (4-methoxyphenyl), -ethyl ester (Bhuiyan et } \\
\text { al. 2008) }\end{array}$ & $\begin{array}{l}\text { anti-hipertensive (Othman } \text { et } \\
\text { al. 2006) } \\
\text { sedative(Huang et al. 2008) } \\
\text { anti-oxidant (Mustafa } \text { et al. } \\
\text { 2010) } \\
\text { anti-microbial (Kanjanapothi } \\
\text { et al. 2004) } \\
\text { anti-microbial (Byuiyan } \text { et al. } \\
\text { 2008) }\end{array}$ \\
\hline Zingiber officinale & $\begin{array}{l}\text { alkaloid; flavonoid; fenolik; triterpenoid } \\
\text { (Kaban } \text { et al. 2016) } \\
\text { minyak atsiri, 1-dehidro-[14]-gingerdiena } \\
\text { (Batubara et al. 2016) }\end{array}$ & $\begin{array}{l}\text { antioxidant (Kaban et al. } \\
\text { 2016) } \\
\text { antioxidant, anti-replication } \\
\text { (Batubara } \text { et al. 2016) }\end{array}$ \\
\hline
\end{tabular}

Based on the literature review, the active compound content of plants in the composition of betimun has various pharmacological activities, such as antifungal, antibacterial, aromatherapy, antioxidant, antiglycation, sedative, and astringent (Table 2). Alpinia galanga leaves contain essential oils consists of 6 compounds and dominated by 1,8-cineole (28.3\%) (Jirovetz et al., 2003). That essential oil acts as aromatherapy which enhances the fragrance of the betimun herb. The plant also contains methanol, acetone, and diethyl ether compounds that role as antibacterial (Rao et al., 2010). The content plays a role in reducing body odor because the antibacterial activity can eliminate bacteria that cause body odor.

The essential oil content in the leaves of Blume balsamifera is composed of 11 compounds. The highest concentration compound is caryophyllene (19.28\%) which takes part as antitumor and antioxidants (Jiang et al., 2014). The other essential oils contents are cineol, borneol, landerol, camphor, tannin, saponin, resin, xantocillin, flavonoids. Those compounds are scientifically proven play important role as antibacterial activity and astringent effects. For example, the antibacterial activity of tannins is able to inhibit bacterial cell wall and protein synthesis by inactivating enzymes and genetic material of bacterial. As a result, the bacterial cells cannot grow due to damage in protein synthesis (Ruhimat 2016). This biological activity contributes to betimun herb efficacy in refreshing the body and eliminating body odor. Furthermore, tannin has an astringent effect that can tighten the skin (Ruhimat 2016). In betimun herb, these effects play a role in helping restore the condition of the mother after giving birth.

Curcuma longa leaves contain steroid compounds and triterpenoids that act as antifungal and anti-bacterial. These compounds can inhibit the growth of microbes such as Staphylococcus aureus and Candida albicans (Septiana and Simanjuntak 2015). The antifungal activity of the leaves of Curcuma longa allows the betimun herb to have the potential to treat vaginal discharge. Thus, besides efficacious in recovery the condition of the mother after giving birth, the herb can also prevent and treat vaginal discharge in women. Meanwhile, Cymbopogon citratus leaves contain essential oils which discover in the form of citral (Sofiah 2010; Manus et al., 2016). Similar to the compound content in the leaves of Curcuma longa, citral compounds also have anti-bacterial and anti-fungal 


\section{STRADA Jurnal Ilmiah Kesehatan}

DOI: $10.30994 /$ sjik.v9i2.257

ISSN: 2252-3847 (print); 2614-350X (online)

Vol.9 No.2 November 2020 Page.1258-1267

properties (Sofiah 2010; Manus et al., 2016). The compound is also used as aromatherapy because of its fragrant and refreshing aroma.

Kaempferia galanga leaves contain hexane extract, ethyl-trans-p-methoxycinnamate, ethyl-cinnamate with biological activity as a sedative (Huang et al., 2008). This sedative activity can reduce the work of the locomotor, causing a calming effect. Moreover, the existence of this activity allows the herb effective in relieving fatigue and aches. The antihypertensive activity of these compounds helps to relax the body (Othman et al., 2006). Furthermore, Kaempferia galanga leaves also contain phenolic, flavonoids, luteolin, and apigenin. These four compounds have anti-oxidant activity so they can neutralize toxins in the body (Mustafa et al., 2010).

The content of essential oils in the leaves of Zingiber officinale is composed of 1dehydro-[14] -gingerdiene compound. Besides having a fragrant and fresh aroma, the compound has antioxidant activity that can slow down the aging process (Coal et al. 2016). Thus, the betimun herb has the potential to keep the user ageless and produce the fragrant to reduce body odor as well. Furthermore, the rise in temperature around the body due to the betimun activity influences the hypothalamic thermostat which response to changes in body temperature. Warm conditions will raise body temperature so that the thermostat activates the cooling mechanism by dilating blood vessels and enlarging the pores of the skin's surface. The purpose of this response is to remove heat from the body through sweat on the surface of the skin (Campbell et al. 2004). Sweat is a metabolic waste so that with the amount of sweat that comes out, then the activity of the cucumber can facilitate the metabolic processes in the body. In addition, the warm condition of the betimun activity also triggers the body to secrete endorphin hormone which can relax the body's muscle cells (Chaichian et al. 2009).

\section{Bioprospection}

The observation regarding the content of active compound in plant composition in betimun herb showed that this herb is scientifically proven to reduce body odor due to the essential oil content of various plants used (Rao et al., 2010; Sofiah 2010; Manus et al., 2016); relieving fatigue and aches (Othman et al., 2006; Huang et al., 2008; Chaichian et al., 2009); preventing and treating vaginal discharge (Septiana and Simanjuntak 2015); helping recovery the condition of the mother after giving birth (Ruhimat 2016; Silalahi and Nisyawati 2019); slowing down the aging process (Mustafa et al., 2010; Coal et al. 2016); and expanding metabolic processes in the body (Campbell et al., 2004). Therefore in terms of ethics, the betimun herb's efficacy based on local beliefs is scientifically correct.

Based on the evidence of the content of active compounds in the used plants, betimun herb has the prospect of being developed into ready-made products i.e. a phytosimplicia. A phyto-simplicia is a natural ingredient made from dried plants' material that is used as medicine. This kind of product has not undergone any processing. To produce a simplicia of betimun herb, three things must be considered, (1) meet the quality parameters of a material such as the correct identification of the type, purity, and stability of the product; (2) meets the quality, safety, and benefits of the product; (3) information on the composition of compounds contained in the product (MOH RI 2000). The existence of ready-made products such as simplicia of betimun herbs can promote the herbal lifestyle in modern society. Also, the use of that product helps preserve the local knowledge of the saibatin indigenous community. 


\section{STRADA Jurnal Ilmiah Kesehatan}

DOI: $10.30994 /$ sjik.v9i2.257

ISSN: 2252-3847 (print); 2614-350X (online)

Vol.9 No.2 November 2020 Page.1258-1267

\section{CONCLUSION}

A total of 6 species from 3 families were used in the preparation of betimun herb. Most species were classified as Zingiberaceae (4 species). Leaves are the used part of all plant species in the betimun herb. The used plant's source came from homegarden. The betimun herb was made by boiling the leaves of the used plants. The betimun herb was performed by covering the user with a sarong and then the herb was placed between his legs. The pharmacological activities contained in the active compound of used plants are anti-fungal, anti-bacterial, antioxidant, aromatherapy, anti-oxidant, antiglycation, sedative, anti-hypertensive, and astringent. This ethnomedicine study proves that the betimun herb can reduce body odor; relieve fatigue and aches; prevent and treat vaginal discharge; recover the condition of the mother after giving birth; slow down the aging process, and expedite metabolic processes in the body.

\section{ACKNOWLEDGMENT}

The author would like to thank the saibain community in Labuhan Mandi Village and Kegeringan Village for their hospitality and assistance during the data collection process.

\section{REFERENCE}

Amiri, M.S., Jabarzadeh P., \& Akhondi, M. (2012). An ethnobotanical survey of medicinal plants used by indigenous people in Zangelanlo district, Northeast Iran. Journal of Medicinal Plants Research, 6 (5) 749--753.

Batubara, R.,P., Zuhud, E.,A.,M., Hermawan, R., \& Tumanggor, R. (2017). Nilai guna spesies tumbuhan dalam oukup (mandi uap) masyarakat Batak Karo. Media Konservasi, 22(1): 79-86.

Bhuiyan, M.,D.,N.,I., Begum, J., \& Anwar, M.,N. (2008). Essential oil of leaves and rhizomes of Kaempferia galanga Linn. The Chittagong University Journal of Biological Sciences, 3(1\&2): 65-76.

Campbell, N.,A., Reece, J.,B., Mitchell, L.,G. (2004). Biologi jilid 3 ed. ke 5. Terj. Biology $5^{\text {th }}$ ed. oleh W. Manalu. Jakarta (ID): Penerbit Erlangga.

Chaichian, S., Akhlaghi, A., Rousta, F., Safavi, M. (2009). Experience of water birth delivery in Iran. Archives of Iranian Medicine, 12(5) 468 - 471.

[MOH RI] Departemen Kesehatan RI. (2000). Parameter standar umum ekstrak tumbuhan obat. Jakarta (ID): Direktorat Jenderal Pengawasan Obat dan Makanan, Kementerian Kesehatan.

Dirjen Bina Pemdes. (2017). Profil Desa: Pekon Kegeringan, Batu Brak, Lampung Barat. Jakarta (ID): Direktorat Umum Pengembangan Masyarakat, Kementerian Dalam Negeri.

Dirjen Bina Pemdes. (2017). Profil Desa: Pekon Labuhan Mandi, Way Krui, Pesisir Barat. Jakarta (ID): Direktorat Umum Pengembangan Masyarakat, Kementerian Dalam Negeri.

Gazzaneo, L.,R.,S., De Lucena, R.,F.,P., \& De Albuquerque, U.,P. (2005). Knowledge and use of medicinal plants by local specialist in an region of Atlantic forest in the state of Pernambuco (Northeastern Brazil). Journal of Ethnobiology and Ethnomedicine, 10, 1-9.

Halid, E., \& Novianti, H. (2017). Tahap awal menjelang pelaksanaan prosesi mome'ati masyarakat Gorontalo. Jurnal Puitika, 13(2) 102-110. 


\section{STRADA Jurnal Ilmiah Kesehatan}

DOI: $10.30994 /$ sjik.v9i2.257

ISSN: 2252-3847 (print); 2614-350X (online)

Vol.9 No.2 November 2020 Page.1258-1267

Hoffman, B., \& Gallaher, T. (2007). Importance indices in ethnobotany. Ethnobotany Research dan Applications, 5 201-218.

Huang, L., Yagura, T., Chen, S. (2008). Sedative activity of hexane extract of Kaempferia galanga L. and its active compounds. Journal Ethnopharmacology, 120, 123-125.

Jiang, Z., Xhou, Y., Ge, W., \& Yuan, K. (2014). Phytochemical compositions of volatile oil from Blumea balsamiferaand their biological activities. Pharmacogn Mag, 10(39), 346-352.

Kaban, A.,N., Tariga, D., \& Saleh, C. (2016). Uji fitokimia, toksisitas dan aktivitas antioksidan fraksi n-heksan dan etil asetat terhadap ekstrak jahe merah (Zingiber officinale var. Amarum). Jurnal Kimia Mulawarman, 14 (1), 24-28.

Kanjanapothi, D., Panthong, A., Lertprasertsuke, N., Taesotikul, T., Rujjanawate, C., Kaewpinit, D., Sudthayakorn, R., Choochote, W., Chaithong, U., Jitpakdi, A., Pitasawat, B. (2004). Toxicity of crude rhizome extract of Kaempferia galanga L. (Proh Hom). Journal of Ethnopharmacology, 90, 359-365.

Kawengian, S.,A., Wuisan, J., \& Leman, M.,A. (2017). Uji daya hambat ekstrak daun serai (Cymbopogon citratus L) terhadap pertumbuhan Streptococcus mutans. Jurnal $e$ GiGi, 5,(1): 7-11.

Lonita, Hendra, M., \& Hariani, N. (2019). Jenis tumbuhan obat tradisional dari masyarakat Dayak Kenyah Uma Baha di Kecamatan Kelay, Kabupaten Berau. Jurnal Pro-Life, 6 (3): 214-223.

Manus, N., YamLean, P.,V.,Y., Kojong, N.,S. (2016). Formulasi sediaan gel minyak atsiri daun sereh (Cymbopogon citratus) sebagai antiseptik tangan. Pharmacon, 5, (3), $85-93$.

Maslahat, M., Nurilmala, F., \& Harpeni, L. (2017). Aktivitas antioksidan ekstrak air simplisia daun sembung (Blumea balsamifera). Jurnal Sains Natural, 3, (2), 129136.

Mustafa RA, Abdul HA, Mohamed S, Bakar FA. (2010). Total phenolic compounds, flavonoids, and radical scavenging activity of 21 selected tropical plants. Journal Food Science, 75, 28-35.

Najamudin. 2018. Pendekatan semiotic dalam analisis legal "Kambang Goyang” karya H. Anang Ardiansyah. Prosiding Seminar Nasional Lingkungan Lahan Basah, 3, (2), $497-499$.

Othman, R., Ibrahim, H., Mohd, M.,A., Mustafa, M.,R., Awang, K. (2006). Bioassayguided isolation of a vasorelaxant active compound from Kaempferia galanga L. Phytomedicine, 13, 61-66.

Pulungan, A.,S.,S. (2017). Aktivitas antijamur ekstrak etanol daun kunyit (Curcuma longa Linn.) terhadap jamur Candida albicans. BIOLINK - Jurnal Biologi Lingkungan Industri Kesehatan, 3, (2), 124-128.

Putri, D.,P., Zuhud, E.,A.,M., Hermawan, R., \& Tumanggor, R. (2017). Keanekaragaman tumbuhan untuk bahan betangas. Media Konservasi, 22, (1), 87-91.

Rao, K., Ch., B., Narasu, L.,M., \& Giri, A. (2010). Antibacterial activity of Alpinia galanga (L.) Willd Crude Extracts. Appl. Biochem Biotechnol, 162, 871-884.

Ruhimat, U. (2015). Daya hambat infusum daun sembung (Blumea balsamifera) terhadap pertumbuhan bakteri Escherichia coli dengan metode difusi cakram. Jurnal Kesehatan Bakti, 13, (1), 142-148.

Sarpinah, Salimin, Syahrir, A.,P. (2018). Nilai-nilai yang terkandung dalam budaya Mappaci pada rangkaian pelaksanaan perkawinan orang Bugis. Selami IPS, 47, (3), $211-218$. 


\section{STRADA Jurnal Ilmiah Kesehatan}

DOI: $10.30994 /$ sjik.v9i2.257

ISSN: 2252-3847 (print); 2614-350X (online)

Vol.9 No.2 November 2020 Page.1258-1267

Septiana, E., \& Simanjuntak, P. (2015). Aktivitas antimikroba dan antioksidan ekstrak beberapa bagian tanaman kunyit (Curcuma longa). Fitofarmaka Jurnal Ilmiah Farmasi, 5, (1), 1-10.

Silalahi, M., \& Nisyawati. (2019). An ethnobotanical study of traditional steam-bathing by the Batak people of North Sumatra, Indonesia. Pacific Conservation Biology, 25, (3), 266-282.

Sofiah, S. (2010). Cymbopogon citratus sebagai salah satu tanaman penghasil minyak atsiri. UPT Balai Konservasi Tumbuhan Kebun Raya, Indonesia.

Vogl, C.,R., Vogl-Lukasser, B., \& Puri, R.,K. (2004). Tools and methods for data collection in ethnobotanical studies of homegardens. Field Method, 16, (3), 285-306.

Wakhidah, A.,Z., Silalahi, M., \& Pradana, D.,H. (2017). Inventory and conservation plant of oke sou traditional ceremony: A welcoming tradition of maturity girl on the community of Lako Akediri Village, West Halmahera, Indonesia. Biodiversitas, 18, (1), 65-72. 